\title{
The Effects of Oxygen on Fermentation in Tritrichomonas foetus KV1 and its Variant 1MR-100 with Defective Hydrogenosomes
}

\author{
By DAVID LLOYD, * CHRISTOPHER J. JAMES, ALUN L. LLOYD, \\ NIGEL YARLETT $\uparrow$ AND NURIZA C. YARLETT \\ Department of Microbiology, University College, Newport Road, Cardiff CF2 ITA, UK
}

(Received 30 October 1986; revised 9 December 1986)

\begin{abstract}
The effects of low concentrations of $\mathrm{O}_{2}$ on fermentation in the cattle parasite Tritrichomonas foetus KV1 and its variant $1 \mathrm{MR}-100$ were compared using membrane inlet mass spectrometry to measure simultaneously and continuously ethanol, $\mathrm{CO}_{2}$ and $\mathrm{H}_{2}$. In strain $\mathrm{KVl}$ glucosesupported $\mathrm{H}_{2}$ and $\mathrm{CO}_{2}$ production were stimulated by $\mathrm{O}_{2}$ concentrations $<1.4 \mu \mathrm{M}$ but were inhibited at higher concentrations. Damped oscillatory responses in $\mathrm{H}_{2}$ production indicated the operation of a feedback control system. Measurement of the $\mathrm{O}_{2}$-dependence of $\mathrm{O}_{2}$ consumption rates confirmed the presence of a high-affinity terminal oxidase (apparent $K_{\mathrm{m}}=1.6 \mu \mathrm{M}-\mathrm{O}_{2}$ at $37^{\circ} \mathrm{C}$ ) and substrate inhibition by $\mathrm{O}_{2}$ at $>8 \mu \mathrm{M}-\mathrm{O}_{2}$. Successive periods of exposure to $\mathrm{O}_{2}$ resulted in decreased $\mathrm{O}_{2}$ scavenging capacity, as indicated by increasing apparent $K_{\mathrm{m}}$ values for $\mathrm{O}_{2}$. The variant strain $1 \mathrm{MR}-100$ which lacks pyruvate :ferredoxin oxidoreductase and hydrogenase showed quite different characteristics: $\mathrm{H}_{2}$ production was not detectable, ethanol formation was inhibited by $\mathrm{O}_{2}\left(K_{\mathrm{i}}=1 \mu \mathrm{M}\right)$ and $\mathrm{O}_{2}$-dependence of $\mathrm{O}_{2}$ consumption indicated that no high-affinity oxidase was present (apparent $K_{\mathrm{m}}=33 \mu \mathrm{M}-\mathrm{O}_{2}$ ). Progressive increases in respiration rates on repeated exposure to low $\mathrm{O}_{2}$ concentrations indicated a capacity for adaptation to aerobiosis.
\end{abstract}

\section{INTRODUCTION}

Trichomonads are flagellate protozoa, parasitic in animals and man (Honigberg, 1978a,b); they inhabit locales where periods of strictly anaerobic conditions may alternate with varying levels of $\mathrm{O}_{2}$ supply (Wagner \& Ottesen, 1982). The absence of mitochondria from these organisms (Lloyd et al., $1979 a, b$; Müller, 1980) necessitates the functioning of alternative oxidative sites; cytosolic systems and hydrogenosomes (Müller \& Lindmark, 1978: Cerkasov et al., 1978) both assume this role. In the cytosol highly active nicotinamide nucleotide oxidases specific for NADH (Tanabe, 1979) and NADPH (Linstead, 1983), are believed to play an important part in protecting the oxygen-sensitive enzymes of the hydrogenosome. The hydrogenosome itself has a complex chain of flavin and iron-sulphur electron carriers (Ohnishi et al., 1980; Chapman et al., 1986) using either protons or oxygen as terminal electron acceptors. The production of $\mathrm{H}_{2}$ under anaerobic conditions is diminished in Trichomonas vaginalis when $\mathrm{O}_{2}$ is admitted (Lloyd \& Kristensen, 1985), and the organism has an intense respiration and shows a high affinity for $\mathrm{O}_{2}$ (Lloyd et al., 1982, 1987; Yarlett et al., 1986).

In the cattle parasite Tritrichomonas foetus, succinate and glycerol (Chapman et al., 1985) are produced in the cytosol, whereas acetate and molecular $\mathrm{H}_{2}$ are produced in the hydrogenosomes (Müller, 1976). A metronidazole-resistant variant, $T$. foetus KV1-1 MR-100 (Kulda et al., 1984) lacks the hydrogenosomal enzymes pyruvate:ferredoxin oxidoreductase and hydrogenase (Čerkasovová et al., 1984). Elimination of hydrogenosomal pyruvate metabolism in this strain leads to an increased glycolytic rate and the stoichiometric conversion of each molecule of glucose to two of ethanol plus two of $\mathrm{CO}_{2}$.

† Present address: Haskins Laboratories, Pace University, 41 Park Row, New York NY 10038, USA. 
In the work described in this paper we used continuous monitoring of $\mathrm{H}_{2}, \mathrm{O}_{2}, \mathrm{CO}_{2}$ and ethanol to compare the effects of low levels of $\mathrm{O}_{2}$ on the fermentation products of $T$. foetus strain KV1 with those of strain KV1-1MR-100.

\section{METHODS}

Maintenance, growth and harvesting of the organism. Tritrichomonas foetus strains KV1 and K V1-1MR-100 were cultured in Diamond's liquid TYM medium without agar supplemented with $10 \%(\mathrm{v} / \mathrm{v})$ heat-inactivated horse serum (Diamond, 1957). Stock cultures (5.5 $\mathrm{ml}$ in screw-capped tubes) were subcultured daily and used to inoculate $150 \mathrm{ml}$ of culture medium in screw-capped bottles. Growth at $37^{\circ} \mathrm{C}$ for $24 \mathrm{~h}$ gave a population of 1 to $2 \times 10^{6}$ organisms ml-1. Organisms were harvested at room temperature in a bench centrifuge at $600 \mathrm{gav}_{\mathrm{av}}$ for $2 \mathrm{~min}$, and then washed twice in a phosphate-buffered salt solution, pH 6.9 (Doran, 1959).

Measurements of $\mathrm{O}_{2}, \mathrm{CO}_{2}, \mathrm{H}_{2}$ and ethanol by mass spectrometry. A quadrupole mass spectrometer (Spectramass Dataquad; Spectrum Scientific, Congleton, Cheshire, UK) was used: the inlet consisted of a quartz tube $(3.5 \mathrm{~mm}$ outside diameter) sealed at one end and having a $0.25 \mathrm{~mm}$ diameter hole $5 \mathrm{~mm}$ from its sealed end; silicone rubber sleeve (outside diameter $0.19 \mathrm{~mm}$; inside diameter $0.15 \mathrm{~mm}$ ) was stretched into place over the orifice. Measurements were made in a $2 \mathrm{ml}$ polycarbonate tube $(1 \mathrm{ml}$ working vol.), with the mass spectrometer inlet submerged in reaction mixture. Gas mixtures were bubbled continuously through the cell suspensions at a constant flow rate $(30 \mathrm{ml} \mathrm{min}-1)$ via a nylon tube. The temperature was maintained at $37^{\circ} \mathrm{C}$ by thermostatically heated water which was circulated around the reaction vessel. Gas mixing was done with a single two-way micro-solenoid valve (type 65.231; Kuhnke, Penn, Bucks, UK) with constant pressure gas inlets and microcomputer-regulated time-shared-switching between inlets; argon and $5 \%(\mathrm{v} / \mathrm{v}) \mathrm{O}_{2}$ in $\mathrm{N}_{2}$ were the two gases used.

The vacuum system used for the mass spectrometer was a Pfeiffer Turbomolecular pump (type TPV050) backed by a two-stage Edwards rotary pump (E2M2).

The half-times for equilibration for $\mathrm{O}_{2}, \mathrm{CO}_{2}, \mathrm{H}_{2}$ and ethanol in this system were $0.4,0.3,0.55$ and $0.7 \mathrm{~min}$ respectively giving gas exchange coefficients of $1.73,2.31,1.26$ and $1.0 \mathrm{~min}^{-1}$. Gas solubilities were taken as being $220 \mu \mathrm{M}$ for $\mathrm{O}_{2}$ in air-saturated Doran's buffer, and $705 \mu \mathrm{M}$ for saturated $\mathrm{H}_{2}$ (Wilhelm et al., 1977); $\mathrm{CO}_{2}$ calibration was done by adding standard $\mathrm{NaHCO}_{3}$ solutions to the reaction mixture at $\mathrm{pH}$ 6.9.

\section{RESULTS AND DISCUSSION}

Fig. 1 shows the effects of adding low concentrations of $\mathrm{O}_{2}(<2 \mu \mathrm{M})$ on fermentation in a nonproliferating cell suspension of $T$. foetus $\mathrm{KVl}$. Adding $10 \mathrm{mM}$-glucose gave $30 \%$ stimulation of $\mathrm{H}_{2}$ and $20 \%$ stimulation of $\mathrm{CO}_{2}$ production under anaerobic conditions; the rate of ethanol formation was so low as to be barely detectable $\left(<0.05 \mathrm{nmol} \mathrm{min}{ }^{-1}\right.$ per $10^{6}$ cells $)$. Production rates both of $\mathrm{CO}_{2}$ and $\mathrm{H}_{2}$ showed an overshoot followed by a damped oscillation on adding glucose. Mixing $0.25 \mathrm{kPa} \mathrm{O}_{2}$ into the mobile gas phase resulted in a rapid equilibration to a steady state concentration of $0 \cdot 32 \mu \mathrm{M}-\mathrm{O}_{2}$ in solution. This low concentration of $\mathrm{O}_{2}$ stimulated $\mathrm{H}_{2}$ production $(9 \%)$ and $\mathrm{CO}_{2}$ production $(17 \%)$. Further stimulation of $\mathrm{H}_{2}$ production was observed on increasing dissolved $\mathrm{O}_{2}$ to $0.53 \mu \mathrm{M}$; at $\mathrm{O}_{2}$ concentrations greater than $1.3 \mu \mathrm{M}$, the $\mathrm{H}_{2}$ concentration began to decline. The concentration of $\mathrm{CO}_{2}$ increased until $\mathrm{O}_{2}$ exceeded $1.6 \mu \mathrm{M}$. Overshoots both in $\mathrm{H}_{2}$ and $\mathrm{CO}_{2}$ concentrations were evident after every $\mathrm{O}_{2}$ addition.

Increasing $\mathrm{O}_{2}$ concentrations further gave progressively decreased $\mathrm{H}_{2}$ and $\mathrm{CO}_{2}$ production (not shown); $K_{\mathrm{i}}$ values for the inhibition by $\mathrm{O}_{2}$ were 2.3 and $2.5 \mu \mathrm{M}$ respectively.

Oxygen consumption by strain KVl (Fig. 2) showed a complex dependence on $\mathrm{O}_{2}$ concentration which was modified by prolonged exposure to $\mathrm{O}_{2}$ concentrations in excess of about $10 \mu \mathrm{M}$. Thus, at first, organisms maintained anaerobically showed a high affinity for $\mathrm{O}_{2}$ (apparent $K_{\mathrm{m}}$ value 1.6 $\mathrm{M}$ ) and substrate inhibition above $8 \mu \mathrm{M}-\mathrm{O}_{2}$. Each $\mathrm{O}_{2}$ concentration was maintained for $10 \mathrm{~min}$ giving a total exposure time of $1 \mathrm{~h}$; then the mobile gas phase was switched back to argon and anaerobic conditions re-established. When the step increases of $\mathrm{O}_{2}$ were repeated with the same batch of organisms the respiration rate was lower for any given value of dissolved $\mathrm{O}_{2}$ and the affinity for $\mathrm{O}_{2}$ as determined from a double reciprocal plot was decreased. Successive series of stepwise exposures to $\mathrm{O}_{2}$ produced further increases in the apparent $K_{\mathrm{m}}$ value.

Plot $1(a)$ (Fig. 2) shows the $\mathrm{O}_{2}$-concentration-dependence of respiration at high cell density $\left(3.3 \times 10^{7}\right.$ organisms $\left.\mathrm{ml}^{-1}\right)$ and gives the same extrapolated apparent $K_{\mathrm{m}}$ value $\left(1.6 \mu \mathrm{M}-\mathrm{O}_{2}\right)$ as that obtained at half that cell density (plot 1, Fig. 2). On exposure to $\mathrm{O}_{2}$, washed non- 


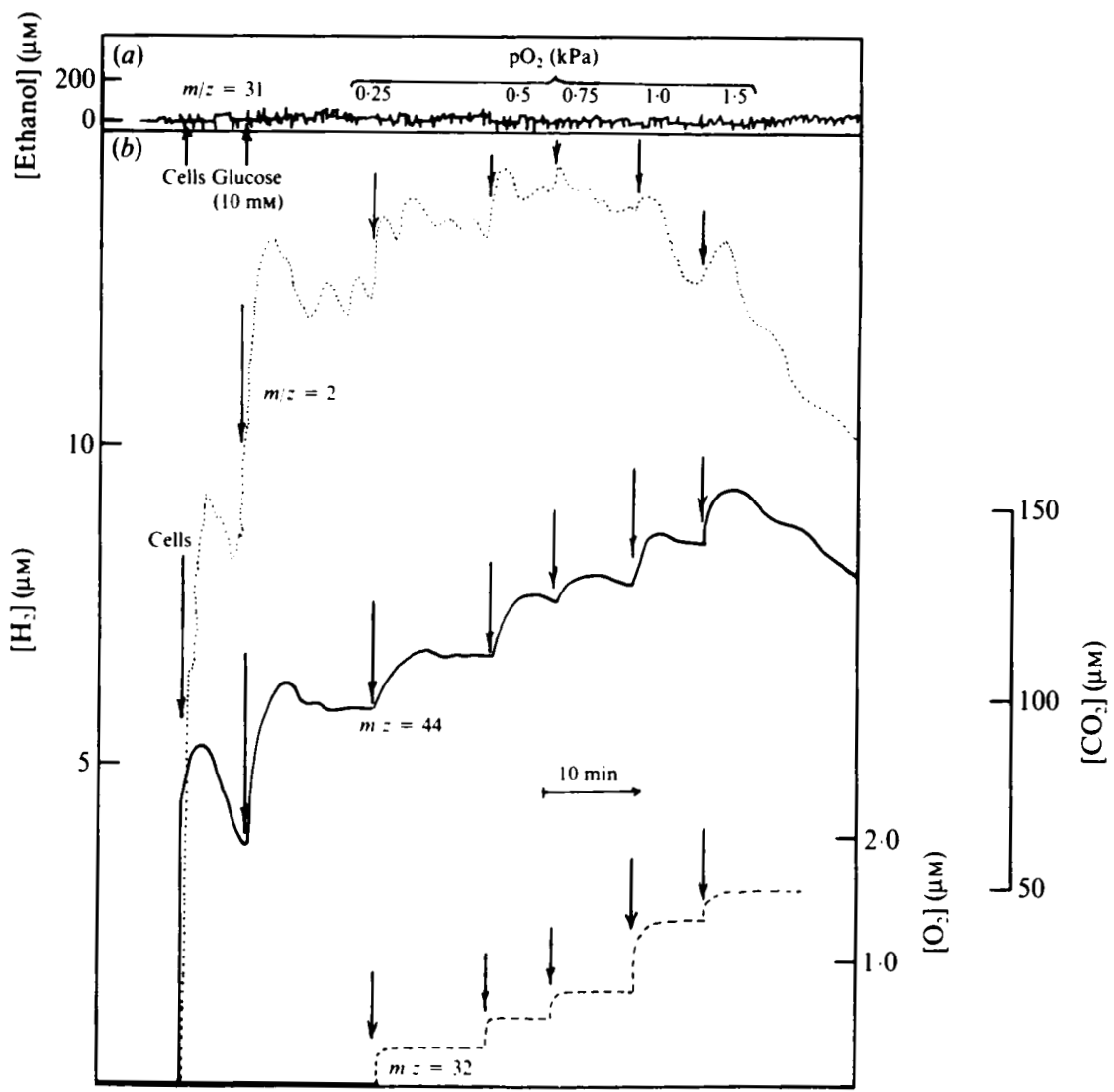

Fig. 1. Effects of low $\mathrm{O}_{2}$ concentrations on ethanol, $\mathrm{H}_{2}$ and $\mathrm{CO}_{2}$ production by $T$. foetus $\mathrm{KV} 1$ during glucose utilization. Washed organisms $\left(2.7 \times 10^{7} \mathrm{ml}^{-1}\right)$ were suspended at $37^{\circ} \mathrm{C}$ in Doran's buffer (pH 6.9) under an atmosphere of argon. Additions were made or the composition of the mobile gas phase was altered at the points marked by arrows. (a) Ethanol $(m / z=31) ;(b) \mathrm{H}_{2}(\cdots), \mathrm{CO}_{2}(\longrightarrow)$ and $\mathrm{O}_{2}(\cdots-)$ measured at $m / z=2,44$ and 32 respectively.

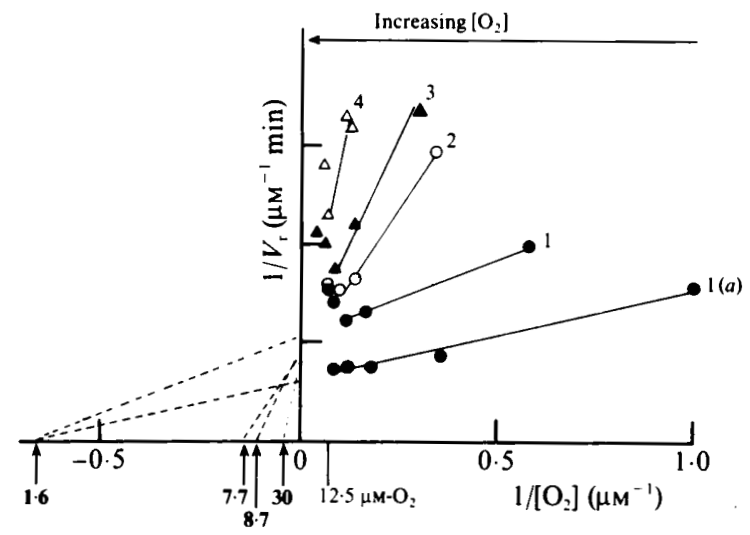

Fig. 2. $\mathrm{O}_{2}$-dependence of glucose-supported $\mathrm{O}_{2}$ consumption rates in $T$. foetus $\mathrm{KVL}$. Plot 1 : conditions and measurements as in Fig. 1 except that $1.5 \times 10^{7}$ organisms $\mathrm{ml}^{-1}$ were exposed to equal stepwise increases of $\mathrm{O}_{2}$ (up to $2 \mathrm{kPa}$ final $\mathrm{pO}_{2}$ ); each concentration was maintained for 10 min and after the fifth step the gas phase was switched to argon. The process was repeated three times (plots 2-4). For plot I (a) $3.3 \times 10^{7}$ organisms ml-1 were exposed to stepwise $\mathrm{O}_{2}$ increases. Apparent $K_{\mathrm{m}}$ values $(\mu \mathrm{M})$ for $\mathrm{O}_{2}$ are indicated in bold type. 


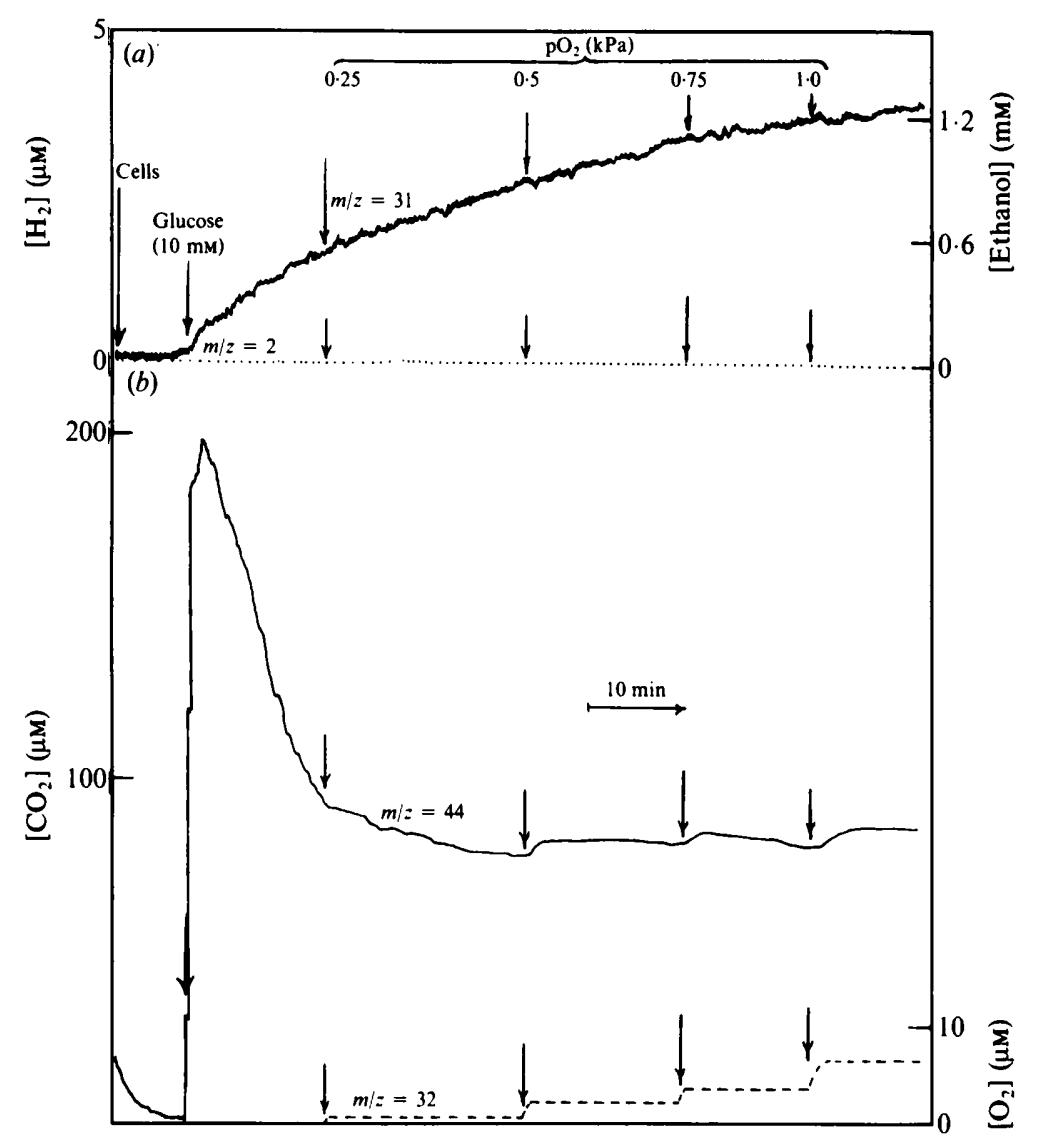

Fig. 3. Effects of low $\mathrm{O}_{2}$ concentrations on ethanol and $\mathrm{CO}_{2}$ production by $T$. foetus $\mathrm{KV} 1-1 \mathrm{MR}-100$ during glucose utilization. Conditions as in Fig. 1 except that the reaction vessel contained $2.5 \times 10^{7}$ organisms $\mathrm{ml}^{-1}$. (a) Ethanol $(-)$ and $\mathrm{H}_{2}(\cdots) ;(b) \mathrm{CO}_{2}(-)$ and $\mathrm{O}_{2}(-\cdots)$.

proliferating organisms progressively lost the capacity to produce $\mathrm{H}_{2}$, and their motility decreased. Whether recovery of these functions is possible if these organisms are returned to growth medium has not been assessed. The slow production of ethanol by this strain was not measurably increased during $\mathrm{O}_{2}$ exposure.

For strain KV1-1MR-100 a very different pattern of responses to $\mathrm{O}_{2}$ was obtained (Fig. 3). Under anaerobic conditions, organisms utilizing glucose showed a high rate of ethanol production and hydrogen was undetectable. As fermentation of glucose commenced a burst of ethanol formation was accompanied by an extensive overshoot in the concentration of dissolved $\mathrm{CO}_{2}$ which relaxed to about a half its maximum value within $15 \mathrm{~min}$. Oxygenation to $0.5 \mu \mathrm{M}-\mathrm{O}_{2}$ gave a marked reduction (about $30 \%$ ) in the ethanol accumulation rate $\left[K_{\mathrm{i}}=1.0 \mu \mathrm{M} \pm 0.04\right.$ $(n=5)]$.

Under anaerobic conditions linear accumulation of ethanol was observed during fermentation of glucose over periods of up to $1 \mathrm{~h}$ and up to $2 \mathrm{mM}$-ethanol.

Further stepwise increases produced only slight stimulation of $\mathrm{CO}_{2}$ production (much less so than was the case for strain $\mathrm{KV}$ ), and the $\mathrm{O}_{2}$-induced overshoots in $\mathrm{CO}_{2}$ production observed with the 'normal' strain were not observed. Double reciprocal plots for the $\mathrm{O}_{2}$ dependence of respiration rates of the variant strain indicated a linear relationship (Fig. 4): the maximum respiratory rates were increased and the apparent $K_{\mathrm{m}}$ value for $\mathrm{O}_{2}$ was greatly increased by comparison with strain KVl. Exposure to $\mathrm{O}_{2}$ gave an adaptation to $\mathrm{O}_{2}$ utilization rather than 


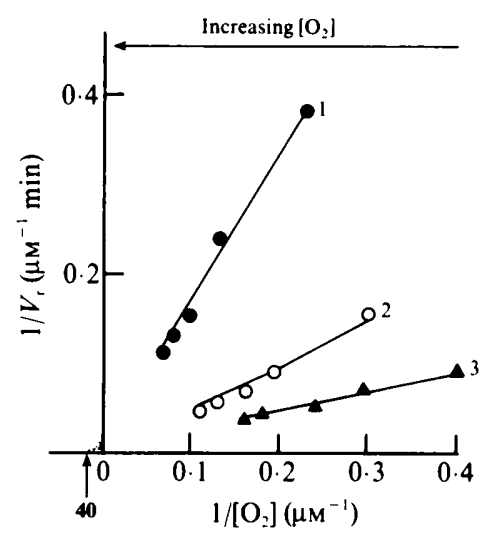

Fig. 4. $\mathrm{O}_{2}$ dependence of glucose-supported $\mathrm{O}_{2}$ consumption rates in $T$. foetus KV1-1MR-100. Conditions, measurements and gas mixing programme were as in Fig. 2 except that the suspension contained $6.3 \times 10^{6}$ organisms $\mathrm{ml}^{-1}$. The apparant $K_{\mathrm{m}}$ value $(\mu \mathrm{M})$ for $\mathrm{O}_{2}$ is indicated in bold type.

Table 1. Characteristics of $\mathrm{O}_{2}$ consumption rates of product formation by $T$. foetus $K V I$ and its variant KVI-1MR-100

Organisms were incubated in the reaction vessel of a mass spectrometer (see Methods) in the presence of $20 \mathrm{mM}$-glucose; results are means \pm SD (number of determinations in brackets). ND, Not detectable i.e. $<0.02 \mathrm{nmol} \mathrm{min}^{-1}$ per $10^{6}$ cells.

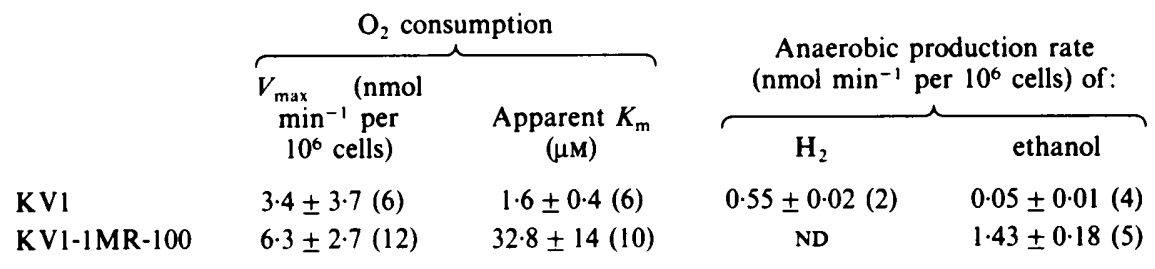

loss of respiratory capacity as observed in strain $\mathrm{KVl}$. A summary of kinetics of fermentation and $\mathrm{O}_{2}$ consumption in the two strains (Table 1) indicates that loss of the hydrogen-producing capability in the variant strain is accompanied by reduced $\mathrm{O}_{2}$-scavenging capacity. The oxygensensitive enzymes, pyruvate : ferredoxin oxidoreductase and hydrogenase are not present in the variant strain (Čerkasovová et al., 1984) and this may explain its increased $\mathrm{O}_{2}$ tolerance.

Further work is necessary to characterize the high-affinity oxidase of hydrogenosomes and the mechanism whereby it is inactivated by $\mathrm{O}_{2}$. Cytochromes are absent from all the trichomonads studied, and it has been argued that a flavoprotein or an iron-sulphur protein are unlikely candidates in this role (Ohnishi et al., 1980; Chapman et al., 1986).

\section{REFERENCES}

Čerkasov, J., Čerkasovová, A., Kulda, J.\& VilhelMOVÁ, D. (1978). Respiration of hydrogenosomes of Tritrichomonas foetus. I. ADP-dependent oxidation of malate and pyruvate. Journal of Biological Chemistry 253, 1207-1214.

Čerkasovová, A., Čerkasov, J. \& Kulda, J. (1984). Metabolic differences between metronidazole resistant and susceptible strains of Tritrichomonas foetus. Molecular and Biochemical Parasitology 11, 105-118.

Chapman, A., Linstead, D., Lloyd, D. \& Williams, J. (1985). ${ }^{13} \mathrm{C}-\mathrm{NMR}$ reveals glycerol as an unexpec-

ted major metabolite of the protozoan parasite Trichomonas vaginalis. FEBS Letters 191, 287-292.

Chapman, A., Cammack, R., Linstead, D. J. \& LloYD, D. (1986). Respiration of Trichomonas vaginalis. Components detected by electron paramagnetic resonance spectroscopy. European Journal of Biochemistry 156, 193-198.

DiAMOND, L. (1957). The establishment of various trichomonads of animals and man in axenic cultures. Journal of Parasitology 43, 488-490.

Doran, D. J. (1959). Studies on trichomonads. III. 
Inhibitors, acid production and substrate utilization by 4 strains of Tritrichomonas foetus. Journal of Protozoology 6, 177-182.

HoNIGBERG, B. M. (1978a). Trichomonads of veterinary importance. In Parasitic Protozoa, vol. 2, pp. 163-273. Edited by J. P. Kreier. New York: Academic Press.

HONIGBERG, B. M. (1978b). Trichomonads of importance in human medicine. In Parasitic Protozoa, vol. 2, pp. 275-454. Edited by J. P. Kreier. New York: Academic Press.

Kulda, J., Čerkasov, J. \& Demeš, P. (1984). Tritrichomonas foetus: stable resistance to metronidazole in vitro. Experimental Parasitology 57, 93-103.

LINSTEAD, D. (1983). Oxygen sensitivity and nitroimidazole action in Trichomonas vaginalis. Wiadomosci parazytologiczne 29, 21-31.

Lloyd, D. \& KRISTENSEN, B. (1985). Metronidazole inhibition of hydrogen production in vivo in drugsensitive and resistant strains of Trichomonas vaginalis. Journal of General Microbiology 131, 849-853.

LLOYD, D., LiNDMARK, D. G. \& MülLER, M. (1979a). Respiration of Tritrichomonas foetus: absence of detectable cytochromes. Journal of Parasitology 65, 466-469.

Lloyd, D., LindmaRK, D. G. \& Müller, M. (1979b). Adenosine triphosphatase activity of Tritrichomonas foetus. Journal of General Microbiology 115, 301-307.

LloYd, D., Williams, J., YaRLetT, N. \& Williams, A. G. (1982). Oxygen affinities of the hydrogenosomecontaining protozoa Tritrichomonas foetus and Dasytricha ruminantium, and two aerobic protozoa, determined by bacterial bioluminescence. Journal of General Microbiology 128, 1019-1022.
Lloyd, D. Yarlett, N., Yarlett, N. C., Pedersen, J. Z. \& KRISTENSEN, B. (1987). Metronidazole-resistant clinical isolates of Trichomonas vaginalis maintain low intracellular metronidazole radical anion levels as a consequence of defective oxygen scavenging. Acta Universitatis Carolinae Biologica (in the press).

MÜLlER, M. (1976). Carbohydrate and energy metabolism of Tritrichomonas foetus. In Biochemistry of Parasites and Host Parasite Relationship, pp. 3-14. Edited by $\mathbf{M}$. Van den Bossche. Amsterdam: Elsevier/North Holland.

MÜLLER, M. (1980). The hydrogenosome. Symposia of the Society for General Microbiology 30, 127-142.

MÜLleR, M. \& LiNDMARK, D. G. (1978). Respiration of hydrogenosomes of Tritrichomonas foetus. II. Effect of $\mathrm{CoA}$ on pyruvate oxidation. Journal of Biological Chemistry 253, 1215-1218.

OHNISHI, T., LlOYD, D., LINDMARK, D. G. \& MÜLLER, M. (1980). Respiration of Tritrichomonas foetus: components detected in hydrogenosomes and intact cells by electron paramagnetic resonance spectrometry. Molecular and Biochemical Parasitology 2, 3950.

TANABE, M. (1979). NADH oxidase in Trichomonas vaginalis. Experimental Parasitology 48, 135-143.

WAGNER, G. \&. OTTESEN, B. (1982). Vaginal physiology during menstruation. Annals of Internal Medicine 96, 921-923.

Wilhelm, E., Battino, R. \& Wilcock, R. J. (1977). Low pressure solubility of gases in liquid water. Chemical Reviews 77, 226-250.

YaRletT, N., YaRletT, N. C. \& Lloyd, D. (1986). Metronidazole-resistant clinical isolates of Trichomonas vaginalis have lowered oxygen affinities. Molecular and Biochemical Parasitology 19, 111-116. 